\title{
Incidence and Glycemic Status of Infants of Diabetic Mothers among 189 Hospitalized Low Birth Weight Babies
}

\author{
Ashith Chandra Das ${ }^{1}$, Md. Tarek Azad ${ }^{2}$, Nure Ishrat Nazme ${ }^{3}$, \\ Jannatul Ferdush Chowdhury ${ }^{4}$, Zainab Rahman ${ }^{5}$, Farzana Rahman ${ }^{6}$
}

\begin{abstract}
Background: The prevalence of gestational diabetes mellitus (GDM) is $9.7 \%$ in Bangladesh. Infants of diabetic mothers (IDM) have a significant chance to develop various complications including glucose instability. Objective: To find out the incidence of IDM among low birth weight (LBW) babies and their relation with blood glucose level during 1 st 48 hours of life. Materials and method: This cross sectional study was conducted from July 2012 to June 2013 on 189 LBW babies with birth weight $<2500$ gram up to 1000 gram admitted within 3 hours of life in the neonatal unit of Jalalabad Ragib Rabeya Medical College Hospital, Sylhet, Bangladesh. Detailed history including maternal history of GDM was taken. Blood glucose level was done during admission and at 3 to $<6$ hours of age, 6 to $<24$ hours of age and 24-48 hours of age. Results: Among 189 cases, male baby were 136 and female baby were 53. Preterm babies were $49.2 \%$ and term babies were $50.8 \%$. Most of the newborn babies were delivered at hospital (78.3\%) and by vaginal delivery (75.1\%). Among LBW babies, 5\% were infants of diabetic mothers. Hypoglycemia was present in $33.3 \%$ of infants of diabetic mothers which was significantly higher than infants of non-diabetic mothers (5.6\%) within 3 hours of age. Conclusion: Infants of diabetic mothers may present as $L B W$ and may be delivered prematurely and they have high incidence of hypoglycemia during early periods of life.
\end{abstract}

Keywords: IDM; LBW; hypoglycemia.

Delta Med Col J. Jan 2017;5(1):4 - 8

\section{Introduction}

Diabetes mellitus is prevalent among $9.7 \%$ people of Bangladesh. ${ }^{1}$ Gestational diabetes mellitus (GDM) is also prevalent among $9.7 \%$ of all pregnancies in our population. ${ }^{2}$ In western world
2 to $3 \%$ of all pregnancies are currently being diagnosed as GDM. ${ }^{3}$

The newborn infants of diabetic mothers (IDM) undergo a sudden interruption of glucose delivery

1. Assistant Professor, Dept. of Paediatrics, Jalalabad Ragib Rabeya Medical College, Sylhet, Bangladesh.

2. Professor \& Head, Dept. of Paediatrics, Jalalabad Ragib Rabeya Medical College, Sylhet, Bangladesh.

3. Resident Medical Officer, Dhaka Shishu Hospital, Dhaka, Bangladesh.

4. Indoor Medical Officer, Dept. of Paediatrics, Jalalabad Ragib Rabeya Medical College, Sylhet, Bangladesh.

5. Indoor Medical Officer, Dept. of Paediatrics, Jalalabad Ragib Rabeya Medical College, Sylhet, Bangladesh.

6. Indoor Medical Officer, Dept. of Paediatrics, Jalalabad Ragib Rabeya Medical College, Sylhet, Bangladesh.

Correspondence: Dr. Ashith Chandra Das. email: ashith_das@yahoo.com 
in the postpartum period, which, when accompanied by high neonatal insulin levels, results in neonatal hypoglycemia. Hypoglycemia is more common in macrosomic or growth-retarded IDM than in IDM who are of appropriate size for gestational age. ${ }^{4}$ Neonatal hypoglycemia in the macrosomic IDM primarily is caused by a combination of hyperinsulinemia secondary to pancreatic islet cell hyperplasia and removal of the exogenous (maternal) glucose source at the time of delivery. During pregnancy, elevated maternal serum glucose results in elevated fetal serum glucose. Because insulin does not cross the placenta, fetal hyperglycemia results in pancreatic stimulation and subsequent hyperplasia of the fetal islet cells. ${ }^{4,5}$ Perinatal stress may have an additive effect on hypoglycemia secondary to catecholamine and glucocorticoid release and glycogen depletion. ${ }^{6}$ Reactive hypoglycemia in the IDM tends to occur within 2 hours of birth, persists up to 72 hours, and may even last up to 1 week. Symptoms of hypoglycemia include jitteriness, sweating, tachypnea or apnea, seizures, agitation, and respiratory distress. ${ }^{7}$

As the neonate adapts to a state of intermittent enteral supply of glucose from that of continuous transplacental glucose supply of intrauterine life, hypoglycemia, especially in the early neonatal period, is a common event. ${ }^{8}$ This tendency to develop hypoglycemia is accentuated by developmental immaturity of normal adaptive mechanisms like gluconeogenesis, hepatic glycogenolysis and ketogenesis. ${ }^{9}$ The effect of neonatal hypoglycemia on the developing brain, with the potential for long term damage is of great concern. ${ }^{10}$ Hypoglycemia is known to be associated with brain dysfunction and retarded motor development. ${ }^{11}$ Thus hypoglycemia is directly related to neonatal mortality and sometimes with long term morbidity which can be easily prevented if detected in the early periods of life.
Though the incidence of macrosomia (birth weight $\geq 4 \mathrm{~kg}$ ) in IDM is high, but some newborns may be growth retarded or may born prematurely. These low birth weight babies (LBW) also have high tendency to develop hypoglycemia during early periods of life. ${ }^{12}$

The study was designed to find out the incidence of IDM among LBW babies and to evaluate the status of blood glucose level in those babies within first 48 hours of age.

\section{Materials and method}

This hospital based cross sectional study was done in neonatal unit of Jalalabad Ragib Rabeya Medical College Hospital, Sylhet, Bangladesh. Total 189 consecutive cases of low birth weight babies (birth weight $<2500$ gram up to 1000 gram) admitted within 3 hours of age were included in this study. Detailed history including maternal history of GDM was taken and proper physical examination was done in every patient. Blood glucose level was measured just after admission and at 3 to $<6$ hours of age, 6 to $<24$ hours of age and 24 to 48 hours of age. Blood glucose was measured by using glucometer ("Accu Chek Active" Roche, Switzerland). At least one of the samples in each patient was compared with the laboratory test result. Hypoglycemia was defined as blood glucose level $<2.2 \mathrm{mmol} / \mathrm{L}$ and hyperglycemia as blood glucose level $>6.9$ $\mathrm{mmol} / \mathrm{L}$ in case of term baby and $>8.3 \mathrm{mmol} / \mathrm{L}$ in case of preterm baby. Data analysis was done by SPSS (for Windows, v19) and Microsoft Excel.

\section{Results}

Total numbers of low birth weight babies enrolled in this study were 189. Among them male baby were 136 and female baby were 53. Male female ratio was $2.57: 1$. Most of the babies (82\%) came from rural area and from middle socio-economic status. Preterm babies were $49.2 \%$ and term babies 
were 50.8\%. Among 189 low birth weight babies, 9 (5\%) were IDM (Figure 1). Out of 9 infants of diabetic mothers, $88.9 \%$ were preterm, which was $47.2 \%$ in case of infants of non-diabetic mothers. Most of the newborn babies were delivered at hospital (78.3\%) and by vaginal delivery $(75.1 \%)$. (Table I)

Hypoglycemia was present in $33.3 \%$ infants of diabetic mothers which was significantly higher than infants of non-diabetic mothers $(5.6 \%)$ within 3 hours of age $(p<0.05)$. (Table II)

Table I: Socio-demographic data of the study population $(\mathrm{N}=189)$

\begin{tabular}{|c|c|c|c|c|c|}
\hline Variables & & $\begin{array}{l}\text { Infants of } \\
\text { diabetic } \\
\text { mothers } \\
n=9(\%)\end{array}$ & $\begin{array}{c}\text { Infants of } \\
\text { non-diabetic } \\
\text { mothers } \\
\text { n=180 }(\%)\end{array}$ & $\begin{array}{c}\text { Total } \\
\mathrm{N}=189(\%)\end{array}$ & $p$ value \\
\hline \multirow[t]{2}{*}{ Sex } & Male & $7(77.8)$ & $129(71.7)$ & $136(72.0)$ & \\
\hline & Female & $2(22.2)$ & $51(28.3)$ & $53(28.0)$ & \\
\hline Residential & Rural area & $6(66.7)$ & $149(82.8)$ & $155(82.0)$ & \\
\hline status & Urban area & $3(33.3)$ & $31(17.2)$ & $34(18.0)$ & \\
\hline Socio-economic & Middle class & $8(88.9)$ & $147(81.7)$ & $155(82.0)$ & \\
\hline status & Poor & $1(11.1)$ & $33(18.3)$ & $34(18.0)$ & $>0.05$ \\
\hline \multirow[t]{2}{*}{ Gestational age } & Preterm & $8(88.9)$ & $85(47.2)$ & $93(49.2)$ & \\
\hline & Term & $1(11.1)$ & $95(52.8)$ & $96(50.8)$ & \\
\hline Place of & Home & $1(11.1)$ & $40(22.2)$ & $41(21.7)$ & \\
\hline delivery & Hospital & $8(88.9)$ & $140(77.8)$ & $148(78.3)$ & \\
\hline Mode of & NVD* & $6(66.7)$ & $136(75.6)$ & $142(75.1)$ & \\
\hline delivery & LUCS** & $3(33.3)$ & $44(24.4)$ & $47(24.9)$ & \\
\hline
\end{tabular}

*NVD - Normal vaginal delivery

** LUCS - Lower uterine caesarian section

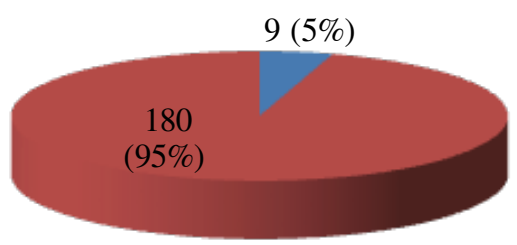

Infants of
diabetic
mothers
Infants of non
diabetic
mothers

Fig. 1: Incidence of infants of diabetic mothers among low birth weight newborn $(\mathrm{N}=189)$
Table II: Glycemic status of infants of diabetic mothers $(n=9)$

\begin{tabular}{|c|c|c|c|c|c|}
\hline \multirow{2}{*}{ Age (hrs) } & \multirow[t]{2}{*}{ Glycemic status } & \multicolumn{2}{|c|}{ Infants of diabetic mothers } & \multirow{2}{*}{ Total } & \multirow{2}{*}{$\mathrm{p}$ value } \\
\hline & & Yes & No & & \\
\hline \multirow{3}{*}{$<3$ hours } & Hypoglycemia & $3(33.3)$ & $10(5.6)$ & 13 & 0.01 \\
\hline & Normoglycemia & $6(66.7)$ & $147(81.7)$ & 153 & 0.49 \\
\hline & Hyperglycemia & $0(0.0)$ & $23(12.7)$ & 23 & 0.53 \\
\hline \multirow{3}{*}{3 to $<6$ hours } & Hypoglycemia & $0(0.0)$ & $01(0.5)$ & 01 & 0.82 \\
\hline & Normoglycemia & $9(100)$ & $151(83.9)$ & 160 & 0.40 \\
\hline & Hyperglycemia & $0(0.0)$ & $28(15.6)$ & 28 & 0.42 \\
\hline \multirow{3}{*}{6 to $<24$ hours } & Hypoglycemia & $0(0.0)$ & $01(0.5)$ & 01 & 0.82 \\
\hline & Normoglycemia & $9(100)$ & $148(82.3)$ & 157 & 0.35 \\
\hline & Hyperglycemia & $0(0.0)$ & $31(17.2)$ & 31 & 0.37 \\
\hline \multirow{3}{*}{24 to 48 hours } & Hypoglycemia & $0(0.0)$ & $01(0.5)$ & 01 & 0.82 \\
\hline & Normoglycemia & $9(100)$ & $162(90)$ & 171 & 068 \\
\hline & Hyperglycemia & $0(0.0)$ & $17(9.5)$ & 17 & 0.71 \\
\hline
\end{tabular}

\section{Discussion}

In this study, among 189 LBW babies male were $136(72 \%)$ and female were $53(28 \%)$. Male female ratio was 2.57:1. This result was consistent with Nadeem et al. where male was $65.4 \%$ and female was $34.6 \%{ }^{13}$

Majority $(82 \%)$ of these LBW babies came from rural area and from middle socio-economic status. This finding is contrary to the results of Arefin et al. who found that $56 \%$ LBW babies came from urban and 44\% came from rural area, again 43\% were from middle socioeconomic status and 57\% were from poor socio economic status. ${ }^{14}$

In our study, most of the LBW infants of diabetic mothers were born preterm $(88.9 \%)$ and it was $47.2 \%$ in case of infants of non-diabetic mothers. But the result was not significant. Most of the babies were delivered at hospital $(78.3 \%)$ and by vaginal delivery $(75.1 \%)$. Arefin et al. observed almost similar finding where $36 \%$ LBW babies were delivered at home and $64 \%$ at hospital. ${ }^{14}$

Out of 189 newborns, $9(5 \%)$ had history of maternal diabetes mellitus. In a study Mahmood et al. found $7.6 \%$ IDM were low birth weight. ${ }^{15}$ In 
another study, Thomas et al. found that $4.7 \%$ infants of diabetic mothers were low birth weight. ${ }^{16}$ Both studies are similar to our study.

Among infants of diabetic mothers of our study, $33.3 \%$ was hypoglycemic within 3 hours of life, whereas it was only $5.6 \%$ in case of infants of non-diabetic mothers. This study revealed that hypoglycemia was significantly associated with infants of diabetic mothers within 3 hours of life $(p<0.05)$. None of the babies developed hypoglycemia after 3 hours of age. Begum et al. ${ }^{17}$ found in their study that $50 \%$ of infants of diabetic mothers were hypoglycemic at 4 hours of age, whereas Dhananjaya et al. ${ }^{18}$ found that hypoglycemia was present in $40 \%$ of infants of diabetic mothers during first three days of life. Both studies are nearly similar to our study.

\section{Conclusion}

Infants of diabetic mothers may present as LBW and deliver prematurely. As there is high incidence of hypoglycemia in these babies during early periods of life, proper maternal history should be taken regarding maternal diabetes during admission of preterm and LBW babies. Glycemic status should also be closely monitored during early periods of life to prevent hypoglycemia related complications in LBW infants of diabetic mothers.

\section{References}

1. Akter S, Rahman MM, Abe SK, Sultana P. Prevalence of Diabetes and Prediabetes and Their Risk Factors among Bangladeshi Adults: A Nationwide Survey. Bulletin of the World Health Organization. 2014;92:204-13.

2. Jesmin $\mathrm{S}$, Akter $\mathrm{S}$, Akashi H, Al-Mamun A, Rahman MA, Islam MM, et al. Screening for Gestational Diabetes Mellitus and Its Prevalence in Bangladesh. Diabetes Res Clin Pract. 2014;103(1):57-62 .
3. Kuhl C. Insulin Secretion and Insulin Resistance in Pregnancy and GDM. Diabetes. 1991;40:18-24.

4. Kicklighter SD. Infant of Diabetic Mother. Emedicine [Internet]. 2001Oct 26 [cited $2004 \mathrm{Feb}$ 25]. Available from:http://www.emedicine.com/ ped/topic485.htm.

5. Creasy RK, Resnik R. Intrauterine Growth Restriction. In: Creasy RK, Resnick R, editors. Maternal-Fetal Medicine. 4th ed. Philadelphia: WB Saunders; 1999. p.569-84.

6. Polk DH. Disorders of Carbohydrate Metabolism. In: Tausch HW, Ballard RA, editors. Avery's Diseases of the Newborn. 4th ed. Philadelphia: WB Saunders; 1998. p.1235-42.

7. Nold JL, Georgieff MK. Infants of Diabetic Mothers. Pediatr Clin N Am. 2004;51:619-37.

8. Haninger NC, Farley CL. Screening for Hypoglycemia in Healthy Term Neonates: Effects on Breastfeeding. J Midwifery Women's Health. 2001;46:292-301.

9. Stanley CA, Baker L. The Causes of Neonatal Hypoglycemia. N Engl J Med. 1999;340:1200-201.

10. Menni F, de Lonlay P, Sevin C, Touati G, Peigne C, Barbier V, et al. Neurologic Outcomes of 90 Neonates and Infants with Persistent Hyperinsulinemic Hypoglycemia. Pediatrics. 2001;107:476-79.

11. World Health Organization [Internet]. Hypoglycemia of the Newborn: Review of the Literature. 1997 [cited 2004 Feb 25]. Available from:http://apps.who.int/iris/bitstream/10665/63362 /1/WHO_CHD_97.1.pdf.

12. Opara PI, Jaja T, Onubogu UC. Morbidity and Mortality amongst Infant of Diabetic Mothers Admitted into a Special Care Baby Unit in Port Harcourt, Nigeria. Italian J Pedia. 2010;36:77.

13. Nadeem M, Murray DM, Boylan GB, Dempsey ME, Ryan CA. Early Blood Glucose Profile and Neurodevelopmental Outcome at Two Years in Neonatal Hypoxic-Ischaemic Encephalopathy. BMC Pediatrics. 2011;11(10):2-6.

14. Arefin MS, Matin MA, Chowdhury MAKA, Ali ML, Ahmad SS, Bhuyan AH, etal. A Comparative Study between the Outcome of Very Low Birth Weight and Low Birth Weight Hospitalized Babies. The ORION Medical Journal. 2008;31(9):579-82. 
15. Mahmood CB, Kayes MI. Problems and Immediate Outcome of Infant of Diabetic Mothers. J Bangladesh Coll of Phys Surg. 2008;26:67-72.

16. Thomas N, Chinta AJ, Sridhar S, Kumar M, Kuruvilla K, Jana AK. Perinatal Outcome of Infants Born to Diabetic Mothers in a Developing Country Comparison of Insulin and Oral Hypoglycemic Agents. Indian Pedia. 2013;50:289-93.
17. Begum NN, Hassan MQ, Nessa M, Azad K. Influence of Maternal Glycemic Status (HbAlc) at Delivery and Risk of Hypoglycemia in Infants of Diabetic Mothers. Birdem Med J. 2012;2(2):84-88.

18. Dhananjayaa CD, Kiran B. Clinical Profile of Hypoglycemia in Newborn Babies in a Rural Hospital Setting. Int J Biol Med Res. 2011;2(4): 1110-14. 